"Stability and profitability in the Chinese banking industry: evidence from an auto-regressive-distributed linear specification"

\begin{tabular}{|c|c|c|}
\hline AUTHORS & \multicolumn{2}{|l|}{$\begin{array}{l}\text { Yong Tan } \\
\text { John Anchor }\end{array}$} \\
\hline ARTICLE INFO & \multicolumn{2}{|c|}{$\begin{array}{l}\text { Yong Tan and John Anchor (2016). Stability and profitability in the Chinese } \\
\text { banking industry: evidence from an auto-regressive-distributed linear } \\
\text { specification. Investment Management and Financial Innovations, 13(4), 120- } \\
\text { 129. doi:10.21511/imfi.13(4).2016.10 }\end{array}$} \\
\hline DOI & \multicolumn{2}{|c|}{ http://dx.doi.org/10.21511/imfi.13(4).2016.10 } \\
\hline RELEASED ON & \multicolumn{2}{|l|}{ Thursday, 15 December 2016} \\
\hline JOURNAL & \multicolumn{2}{|c|}{ "Investment Management and Financial Innovations" } \\
\hline FOUNDER & \multicolumn{2}{|c|}{ LLC "Consulting Publishing Company "Business Perspectives" } \\
\hline \multirow{2}{*}{ NUMBER OF REFERENCES } & & $\begin{array}{l}\text { ニE: } \\
\text { ニE: }\end{array}$ \\
\hline & NUMBER OF FIGURES & NUMBER OF TABLES \\
\hline 0 & 0 & 0 \\
\hline
\end{tabular}

(C) The author(s) 2023. This publication is an open access article. 
Yong Tan (United Kingdom), John Anchor (United Kingdom)

\title{
Stability and profitability in the Chinese banking Industry: evidence from an auto-regressive-distributed linear specification
}

\begin{abstract}
The important role played by the Chinese commercial banks in the development of China's economy has made the government and banking regulatory authority concerned about the performance of these banks.Indeedthe stability of the banking sector has attracted greater attention since the financial crisis of 2007-2009. The principal objective of this study is to investigate the inter-relationships between profitability and stability in the Chinese banking industry. Using a sample of Chinese commercial banks over the period 2003-2013, the study examines the inter-relationships under an auto-regressive-distributed linear model. Both Z-score and stability inefficiency were used as measures of stability, while Return on Assets (ROA) was used as the indicator of profitability. Different types of Generalized Method of Moments (GMM) estimators including difference GMM, one-step system GMM, two-step system GMM as well as two-step robust GMM were used. In order to the check the robustness of the results, alternative econometric techniques were used, such as ordinary least square (OLS) estimator, between effect estimator, as well as fixed effect estimator. The results show that higher insolvency risk/lower bank stability leads to higher profitability of Chinese commercial banks and also that higher profitability leads to higher bank fragility.
\end{abstract}

Keywords: bank profitability, bank risk, China.

JEL classification: G21, C23.

\section{Introduction}

Profitability is central to the operation of commercial banks, while stability is also of concern to the banking regulatory authorities, particularly since the financial crisis of 2008-2009. The empirical literature not only investigates risk-taking behavior, but also links the risk to the efficiency of commercial banks (Abedifar et al., 2013; Tan and Floros, 2013).

A few studies test the impact of risk-taking behaviour on bank profitability; however, they mainly focus on credit risk (Tennant and Sutherland, 2014; Dietrich and Wanzenried, 2011). Although Tan (2016) investigates the impacts of credit risk as well as insolvency risk on Chinese bank profitability, the impact of profitability on risktaking behavior in the Chinese banking industry has not obtained enough attention from scholars. There is only one study investigating the inter-relationship between insolvency risk and profitability in the Chinese banking industry under a Seemingly Unrelated Regression (Tan and Floros, 2014). The current study focuses on the analysis of insolvency risk and its relationship with bank profitability in China due to the fact that several rounds of banking reforms in China have aimed to reduce risk-taking behavior and improve bank performance. Whether the reforms can achieve these two goals at the same time is is of great concern to by the Chinese government as well as the banking regulatory

(C) Yong Tan, John Anchor, 2016.

Yong Tan, Dr, University of Huddersfield Business School,

Huddersfield, Queensgate, UK.

John Anchor, Professor, University of Huddersfield Business School,

Huddersfield, Queensgate, UK. authorities regulatory authorities. In other words, investigating the inter-relationship between insolvency risk and bank profitability in China, in particular the impact of profitability on insolvency risk, will provide important insights for policy makers and will also significantly contribute to the banking literature.

This study extends the work of Tan and Floros (2014) by testing the inter-relationships between profitability and insolvency risk using a number of econometric techniques under an auto-aggressivedistributed linear specification ${ }^{1}$. However, rather than using the Z-score as the insolvency risk indicator, the current study uses stability inefficiency as well. Different econometric techniques, together with a more precise stability indicator (stability inefficiency) will provide more robust results compared to Tan and Floros (2014). We use an unbalanced panel dataset of 100 Chinese commercial banks over the period 2003-2013. The sample includes three different ownership types (state-owned commercial banks (SOCBs), jointstock commercial banks (JSCBs) and city commercial banks (CCBs)).

The findings of our paper show that Chinese commercial banks with higher levels of insolvency risk have higher profitability, while higher insolvency risk leads to higher profitability.

The paper is structured as follows: section 1 reviews the empirical literature on bank profitability in China. Section 2 presents the data

\footnotetext{
1 Simultaneous equations were specified and estimated under a Seemingly Unrelated Regression (SUR) by Tan and Floros (2014).
} 
and methodology. Section 3 discusses the results, while final Section provides a summary of the whole paper.

\section{Literature review on bank profitability in China}

The profitability in the Chinese banking sector has been extensively tested by the empirical literature. Shih et al. (2007) evaluated the performance of a sample of Chinese commercial banks in 2002 under a principal analysis. The results indicate that jointstock commercial banks have better performance compared to state-owned commercial banks and city commercial banks. Their findings further suggest that bank size does not have any significant impact on bank performance in China.

Using a sample of Chinese commercial banks over the period 2000-2005, Sufian and Habibullah (2009) investigated the impact of credit risk on bank profitability. Their results suggest that credit risk has a significant and positive impact on the profitability of Chinese state-owned commercial banks and jointstock commercial banks. In addition, Sufian (2009) used four state-owned commercial banks and twelve joint-stock commercial banks during 2000-2007 to examine the determinants of bank profitability in China with a focus on the credit risk and liquidity risk under a fixed effect model. The results show that Chinese commercial banks with higher levels of credit risk and liquidity risk have higher profitability.

Heffernan and $\mathrm{Fu}$ (2010) analyzed the profitability of Chinese commercial banks over the period 19992006 using two econometric techniques including a Generalized Method of Moments (GMM) estimator, as well as a fixed effect estimator. Their findings report that bank efficiency, bank listing, GDP growth rate and unemployment are significantly related to bank profitability.

More recently, Tan and Floros (2012a, 2012b, 2012c) used a sample of Chinese commercial banks over the period 2003-2009 to examine the determinants of bank profitability with a focus on the impacts of credit risk and competition on bank profitability under a GMM estimator. The competition is measured by 3-bank and 5-bank concentration ratios. To be more specific, Tan and Floros (2012a) used both 3-bank concentration ratio and 5-bank concentratio ratio to investigate the joint effects of credit risk and competition on bank profitability in China. They do not find any significant impact. The findings from $\mathrm{Tan}$ and Floros (2012b) show that the profitability of Chinese commercial banks is significantly affected by credit risk. Finally, the results from Tan and Floros (2012c) report that Chinese joint-stock commercial banks with higher levels of credit risk have higher profitability.

Using a sample of Chinese commercial banks over the period 2003-2009, Tan and Floros (2014) investigated the inter-relationships between risk, profitability and competition in the Chinese banking industry. Two types of risk are considered which are credit risk and insolvency risk while the competitive condition is measured by the Lerner index. They also use the Seemingly Unrelated Regression to analyze the inter-relationships. The results show that there is a negative impact of competition on bank profitability in China while there is no robust impact of different types of risk on bank profitability in China.

Using a sample of Chinese commercial banks over the period 1997-2004, Garcia-Herrero et al. (2009) explained the low profitability in the Chinese banking industry with a focus on the impacts of competition and efficiency on bank profitability. The authors use a GMM estimator as the econometric technique. Efficiency is measured by the parametric stochastic frontier approach while the competition is measured by the HerfindahlHirshman index. The results show that Chinese commercial banks with higher efficiency have higher levels of profitability and there is no clear impact of competition on bank profitability in China.

More recently, Tan (2016) used a sample of Chinese commercial banks over the period 2003-2011 to examine the impacts of risk and competition on bank profitability in China under a GMM estimation. Two types of risk are evaluated which are credit risk, and insolvency risk and the competition is measured by the Lerner index. The results show that there is no robust impact of risk and competition on bank profitability in China.

Through reviewing the related literature, it is clearly shown that although there are studies investigating the impact of insolvency risk on bank profitability in China with a focus on credit risk and liquidity risk, they mainly focus on using either the generalized method of moments estimator or seemingly unrelated regression. This study contributes to the empirical literature by being the first piece of research using the auto-aggressive-distributed linear specification to test and the inter-relationships between insolvency risk and profitability in banking industry, while causality is tested using a number of different econometric techniques which is supposed to provide more accurate and robust results compared to previous empirical banking literature.

\section{Data and methodology}


We use 5 state-owned commercial banks, 12 jointstock commercial banks and 83 city commercial banks over the period 2003-2013 to test the interrelationships between insolvency risk and bank profitability. The insolvency risk is measured by using two alternative indicators which are Z-score and stability inefficiency, while the profitability is measured by Return on Assets. The data are collected from Bankscope database. Table 1 (see Appendix) shows the summary statistics of the variables used in the current study. The table shows that although insolvency risk measured by stability inefficiency in the Chinese banking industry, is not as stable as the profitability of Chinese commercial banks, it is still less volatile than the insolvency risk measured by the $\mathrm{Z}$-score. Due to the fact that stability inefficiency focuses on the insolvency condition of the whole banking industry, while Zscore concentrates on the levels of insolvency risk of commercial banks, the findings suggest that Chinese commercial banks have a larger difference in insolvency risk across the period examined, while the whole banking industry has less volatility in terms of banking industry stability.

Tables 2a-2d (see Appendix) present the descriptive statistics of the two different profitability measures for the whole Chinese banking industry, as well as for different ownership types. The tables show that the profitability of CCBs is the highest over the examined period followed by SOCBs, while the profitability of JSCBs is the lowest. When looking at the profitability of different ownership types of Chinese commercial banks on a year by year basis, Figure 1 (see Appendix) shows that, in general, SOCBs and CCBs have higher profitability than JSCBs.

Figure 2 (see Appendix) shows the insolvency risk of different ownership types of Chinese commercial banks over the period 2003-2013 as measured by Zscore. The figure indicates that over the period 20032006, state-owned, joint-stock and city commercial banks in China have the same levels of insolvency risk, while the big difference of insolvency risk among these three different ownership types of Chinese commercial banks is observed over the period 20072013. In particular, it is noticed that of 2007 and 2013, the insolvency risk of state-owned commercial banks in China kept increasing, while the insolvency risk between joint-stock commercial banks and city commercial banks was the same over the period. This figure further indicates that over the period 2007-2013, state-owned commercial banks had lower levels of insolvency risk compared to the other ownership types. This reflects the fact that from 2007 onward, stateowned commercial banks had higher volumes of return on assets, together with larger volumes of equity capital as well as small volatility of return on assets. They have lower insolvency risk as measured by the Zscore compared to the other two ownership types.

We also look at the insolvency risk of the Chinese banking industry on a year by year basis, which is reflected by stability inefficiency Figure 3 (see Appendix). The figure shows that the risk conditions in the Chinese banking sector over the period 20032006 were highly volatile; while during 2007-2013, the volatility reduced. The stronger volatility over the period 2003-2006 can be explained by the fact that there is a large amount of non-performing loans in Chinese commercial banks, especially SOCBs, and that the capital level of SOCBs is quite low. Furthermore, the Chinese government initiated a number of measures to deal with it, such as capital injection and non-performing loan write-off, while the financial crisis of 2007-2008 induces bank managers to be more careful in conducting business. The 2008 Olympic Games held in Beijing further promotes the economic growth of China. The resultant decline in the probability of default decreases the risk and increases the capital levels of Chinese commercial banks, which further improves stability in the Chinese banking sector.

We use an auto-aggressive-distributed linear specification to test the inter-relationships between profitability and insolvency risk following Casu and Girardone (2009). The method can test not only the short term causal relationship between stability and profitability, but more importantly, also the long-run inter-relationship. It can be expressed as follows:

$$
\begin{array}{r}
y_{i t}=\alpha_{0}+\alpha_{1} y_{i, t-1}+\alpha_{2} y_{i, t-2}+\beta_{1} x_{i, t-1} \\
+\beta_{2} x_{i, t-2}+\theta_{t}+\delta_{i}+\mu_{i t}
\end{array}
$$

where y represents either a profitability indicator (ROA) (Tan, 2016; Daly and Zhang, 2016) or an insolvency risk indicator (Z-score ${ }^{1}$ or stability inefficiency ${ }^{2}$ ), $i$ and $t$ represent specific banks operating in a specific year, $\alpha_{0}$ is the intercept, $\alpha_{1}$, $\alpha_{2}, \beta_{1}$, and $\beta_{2}$ are the coefficients to be estimated, $\theta_{t}$ is the time effect, $\delta_{i}$ stands for individual bank effect, and $\mu_{i t}$ is the error term. ROA shows the profits earned per unit of assets and reflects management ability to utilize banks' financial and real investment resources to generate profits. ROA has emerged as the key ratio for the evaluation of

\footnotetext{
${ }^{1}$ The Z-score is an indicator to measure the financial health and risk condition of banks. The calculation of Z-score can be expressed as: $Z=\frac{R O A+E / A}{\sigma(R O A)}$. To control for outliers and skewness of the

distribution, the logarithm of Z-score is used (Abedifar et al., 2013). There are few observations with negative Z-score, because we use the logarithm of Z-score, these observations have been dropped out.

${ }^{2}$ See appendix for the estimation.
} 
bank profitability and has become the most common measure of bank profitability (Athanasoglou et al., 2008; Garcia-Herrero-et al., 2009; Golin, 2011). Before conducting the econometric analysis, an augmented Dickey Fuller test is used to test whether or not the variables have unit root. The results are reported in Table 3 (see Appendix). The test uses two lagged differences for ROA - stability inefficiency and the logarithm of the Z-score - the results show that all the variables are stationary at the $1 \%$ significance level. The test was been reconducted using fewer or more lagged differences and the first and second lag of stability inefficiency and logarithm Z-score generate the same results. The rejection of unit root of the variables guarantees the valid and accurate results of the model.

We use different types of Generalized Method of Moments (GMM) estimators to estimate the above equation including the GMM difference estimator, the GMM one-step system estimator, the GMM twostep system estimator and the GMM two-step Robust estimator. The GMM difference estimator uses all available lagged values of the dependent variables and lagged values of the exogenous regressors as an instrument (Arellano and Bond, 1991), while the system GMM addresses the issue of unit root property which has been ignored by the difference GMM (Bond, 2002). Compared with the one-step GMM system estimator, the two-step system GMM estimator gives consistent estimates in the presence of heteroskedasticity and autocorrelation (Mileva, 2007). Finally, the two-step Robust GMM estimator is windmeijeier corrected, in order to provide the most efficient estimates (Roodman, 2009). The relationship between profitability and insolvency risk is reported as the sum of the joint-significant coefficients, with a positive (negative) and significant sign representing a positive (negative) causal relationship. The longrun inter-relationships between profitability and insolvency risk are also checked by testing $\beta_{1}+$ $\beta_{2}=0$. If the probability is less than 0.1 , it means there is a long-term effect of one variable on the other. In order to check the robustness of the results, alternative econometric techniques are used, including between-effect estimator, ordinary least square estimator (OLS) and fixed effect estimator.

\section{Results}

Table 4 reports the results with regard to the effect of insolvency risk on bank profitability. The findings show that AR (1) is significant for some cases; in other words, the first-order autocorrelation is present for some cases. All the second order (AR(2)) autocorrelations are rejected which guarantees the consistency of the estimation. The findings show that the second lags of profitability as well as of insolvency risk are significant for most of the cases, which indicates that profitability is influenced by previous years' profitability as well as insolvency risk. The two cases show that an increase in the value of Z-score (lower insolvency risk) causes increases in profitability, while an increase in stability inefficiency (higher insolvency risk) is found to precede an improvement in bank profitability for three cases. The different finding reflected by Z-score and stability inefficiency can be explained by the fact that the actual condition of stability/insolvency risk can be more accurately measured by stability inefficiency rather than the Zscore (Tabak et al., 2012).

Table 5 (see Appendix) shows the impact of profitability on insolvency risk. The results indicate that the insolvency risk at year $t$ is significantly affected by the previous year's insolvency risk. It is found that an increase in ROA causes an increase in Z-score (insolvency risk) only for one case, while the stability inefficiency indicates that an increase in profitability leads to higher insolvency risk in three cases. As discussed previously, we believe that stability inefficiency provides more different findings with regard to banks' insolvency risk. Thus we believe that in the Chinese banking industry, higher bank profitability will increase insolvency risk and lead to bank fragility.

Table 6 and Table 7 (see Appendix) show the inter-relationships between profitability and insolvency risk using the between-effect estimator, OLS, as well as a fixed effect estimator. The findings suggest that profitability and insolvency risk in the current year are significantly influenced by the previous years' values, while an increase in insolvency risk ( $Z$ score) leads to an improvement in bank profitability, while this impact is opposite for stability inefficiency. When stability inefficiency is used as the insolvency risk indicator, it shows that an increase in profitability precedes increases in insolvency risk. All the significant cases from the tables show that there is a long run relationship between insolvency risk and profitability. We believe that the causal and longrun inter-relationship between insolvency risk and profitability in China is significant and positive because of the more accurate estimate of stability generated by stability inefficiency.

\section{Conclusion}

Performance in the banking sector has been an important issue for bank managers, banking regulatory authorities, government and academic researchers. The empirical literature examines comprehensively the profitability of the banking 
sector in different countries/regions. The financial crisis has made banks focus on monitoring and managing risk-taking behaviour.

While most studies have investigated credit risk and insolvency risk, there is only one study (Tan and Floros, 2014) which has tested the interrelationships between profitability and insolvency risk in the Chinese banking industry under a seemingly unrelated regression. Our study extends Tan and Floros (2014) by testing the interrelationships using different econometric techniques under an auto-regressive-distributed linear specification. In addition, we use a number of different econometric techniques to test the interrelationships between risk and profitability in the Chinese banking industry in order to obtain the robust results. Two insolvency risk indicators are used namely Z-score and stability inefficiency.
Interestingly, Z-score and stability inefficiency provide different finding with regard to its interrelationships with bank profitability. Stability inefficiency measures the risk condition in a more concise way. Thus, we believe that the relationship between profitability and insolvency risk in the Chinese banking industry is significant and positive.

Our finding is in line with the risk-return hypothesis and also provides relevant policy advice to the Chinese banking industry. To be more specific, Chinese commercial banks can allocate long-term credit to different businesses and they can also make full use of their available fund to invest in relatively long-term projects. Although there is a mismatch of liquidity between assets and liabilities, the increase in the insolvency risk can be redeemed by the improvement in bank profitability.

\section{References:}

1. Abedifar, P., Molyneux, P. and Taraizi, A. (2013). Risk in Islamic Banking, Review of Finance, 17(6), pp. 2035-2096.

2. Aigner, D., Lovell, C. A. and Schmidt, P. (1977). Formulation and estimation of stochastic frontier production function models, Journal of Econometrics, 6(1), pp. 21-37.

3. Arellano, M. and Bond, S. R. (1991). Some tests of specification for panel data: Monte Carlo evidence and application to employment equations, Review of Economic Studies, 58(2), pp. 277-297.

4. Athanasoglou, P.P., Brissimis, S.N, and Delis, M.D. (2008). Bank-Specific, Industry-Specific and Macroeconomic Determinants of Bank Profitability, Journal of International Financial Markets, Institutions and Money, 18(2), pp. 121-136.

5. Bond, S. (2002). Dynamic Panel data models: a guide to micro data methods and practice, Portuguese Economic Journal, 1(2), pp. 141-162.

6. Casu, B. and Girardone, C. (2009). Testing the relationship between competition and efficiency in banking: A panel data analysis, Economics Letters, 105(1), pp. 134-137.

7. Daly, K. and Zhang, X. (2016). Comparative analysis of the performance of Chinese owned banks' in Hong Kong 2004 - 2010, Journal of Multinational Financial Management, 27, pp. 1-10.

8. Dietrich, A. and Wanzenried, G. (2011). Determinants of bank profitability before and during the Crisis: evidence from Switzerland, Journal of International Financial Markets, Institutions and Money, 21(3), pp. 307-327.

9. Garcia-Herrero, A., Gavila, S, and Santabarbara, D. (2009). What explains the lower profitability of Chinese banks, Journal of Banking and Finance, 33(1), pp. 2080-2092.

10. Golin, J. (2001). The bank credit analysis handbook: a guide for Analysts, Bankers and Investors, Asia: John Wiley and Sons.

11. Heffernan, S. and Fu, M. (2010). Determinants of financial performance in Chinese banking, Applied Financial Economics, 20(20), pp. 1585-1600.

12. Iannotta, G., Nocera, G. and Sironi, A. (2007). Ownership structure, risk and performance in the European banking industry, Journal of Banking and Finance, 31(7), pp. 2127-2149.

13. Liu, H. and Wilson, J.O.S. (2013). Competition and risk in Japanese banking, European Journal of Finance, 19(1), pp. 1-18.

14. Liu, H., Molyneux, P.and Wilson, J. (2013). Competition and stability in European banking: a regional analysis, Manchester School, 81(2), pp. 176-201.

15. Meeusen, W. and Van de Broeck, J. (1977). Efficiency estimation from Cobb-Douglas production functions with composed error, International Economic Review, 18(2), pp. 435-444.

16. Mileva, E. (2007). Using Arellano-Bond Dynamic Panel GMM estimators in Stata, Working paper, Fordham University, USA, 9 July.

17. Roodman, D. M. (2009). A note on the theme of too many instruments, Oxford Bulletin of Economics and Statistics, 71(1), pp. 135-158.

18. Shih, V., Zhang, Q. and Liu, M. (2007). Comparing the performance of Chinese banks: a principle component approach, China Economic Review, 18(1), pp. 15-34.

19. Staikouras, C. and Wood, G. (2004). The determinants of bank profitability in Europe, International Business and Economic Research Journal, 3(6), pp. 57-68. 
20. Sufian, F. and Habibullah, M. S. (2009). Bank specific and macroeconomic determinants of bank profitability: Empirical evidence from the China Banking Sector, Frontier of Economics in China, 4(2), pp. 274-291.

21. Sufian, F. (2009). Determinants of Bank profitability in a Developing Economy: Empirical evidence from the China Banking Sector, Journal of Asia-Pacific Business, 10(4), pp. 201-307.

22. Tabak, B.M., Fazio, D.M. and Cajueiro, D.O. (2012). The relationship between banking market competition and risk-taking: Do size and capitalization matter? , Journal of Banking and Finance, 36(12), pp. 3366-3381.

23. Tan, Y. and Floros, C. (2012a). Bank profitability and inflation: the case of China, Journal of Economic Studies, 39(6), pp. 675-696.

24. Tan, Y. and Floros, C. (2012b). Bank profitability and GDP growth in China: a note, Journal of Chinese Economics and Business Studies, 10(3), pp. 267-273.

25. Tan, Y. and Floros, C. (2012c). Stock market volatility and bank performance in China. Studies in Economics and Finance, 29(3), pp. 211-228.

26. Tan, Y. and Floros, C (2013). Risk, capital and efficiency in Chinese Banking, Journal of International Financial Markets, Institutions and Money, 26, pp. 378-393.

27. Tan, Y. and Floros, C (2014). Risk, profitability and competition: evidence from the Chinese banking, Journal of Developing Areas, 48(3), pp. 303-319.

28. Tan, Y (2016). The impacts of risk and competition on bank profitability in China, Journal of International Financial Markets, Institutions and Money, 40, pp. 85-110.

29. Tennant. D. and Sutherland, R. (2014). What types of bank profit most from fees charged? A cross-country examination of bank-specific and country-specific determinants, Journal of Banking and Finance, 49, pp. 178-190.

\section{Appendix}

\section{Estimation of stability in the Chinese banking sector-stability inefficiency}

Tabak et al. (2012) argue that the potential stability of banks cannot necessarily be reflected by the Z-score ${ }^{1}$. The deviation from the banks' current stability and the maximum stability must be considered. This study provides a measure of the bank's stability inefficiency by estimating a stochastic frontier (Aigner et al., 1977; Meeusen and Van den Broeck, 1977), with the Z-score as the dependent variable of a translog specification. The equation used to estimate the frontier can be expressed as follows:

$$
\begin{aligned}
& \operatorname{Ln}\left(\frac{Z-\text { score }}{W_{2}}\right)_{i t}=\delta_{0}+\sum_{j} \delta_{j} \operatorname{Ln} Y_{j i t}+\frac{1}{2} \sum_{j} \sum_{k} \delta_{j k} \operatorname{Ln} Y_{j i t} \operatorname{Ln} Y_{k i t}+\beta_{1} \operatorname{Ln}\left(\frac{W_{1}}{W_{2}}\right)_{i t}+\frac{1}{2} \beta_{2} \operatorname{Ln}\left(\frac{W_{1}}{W_{2}}\right)_{i t} \\
& +\sum_{j} \theta_{j} \operatorname{Ln} Y_{j i t} \operatorname{Ln}\left(\frac{W_{1}}{W_{2}}\right)+v_{i t}-v_{i t}
\end{aligned}
$$

We represents the input price; this study considers two input prices which are the price of funds (the ratio of interest expenses to total deposits) and the price of capital (the ratio of non-interest expenses to total assets). Y represents four outputs which are total loans, total deposits, other earning assets and non-interest income. The sub-indices $i$ and $t$ represent bank $i$ operating at time $\mathrm{t}$, while $\mathrm{j}$ and $\mathrm{k}$ represent different outputs. The error term $\varepsilon_{i t}$ equals $v_{i t}-v_{i t}$. The term $v_{i t}$ captures the random disturbance which is assumed to be normally distributed and represents the measurement errors and other uncontrolled factors, i.e. $v_{i t} \sim \mathrm{N}\left(0, \sigma_{v}^{2}\right)$. The term $v_{i t}$ captures technical and allocative inefficiency, both under managerial control, and it is assumed to be half-normally distributed, i. e. $v_{i t} \sim N^{+}\left(\mu_{i t}, \sigma_{v}^{2}\right)$. Higher stability inefficiency indicates higher risk, while lower stability inefficiency means that the risk is lower.

Table 1 Descriptive statistics of the variables

\begin{tabular}{|l|l|l|l|l|l|}
\hline Variables & Observations & Mean & Standard Deviation & Minimum & Maximum \\
\hline Stability inefficiency & 1100 & 0.33 & 0.21 & 0.003 & 0.79 \\
\hline Z-score & 814 & 7.28 & 0.81 & -0.92 & 9.85 \\
\hline ROA & 808 & 0.009 & 0.007 & -0.04 & 0.11 \\
\hline
\end{tabular}

\footnotetext{
1 The Z-score reflects the extent to which banks have the ability to absorb losses. Thus, a higher value of Z-score indicates lower risk and greater stability. The Z-score has been widely used in empirical studies to measure the stability of financial institutions (Iannotta et al. 2007; Liu and Wilson 2013, Liu et al., 2013). The Z-score can be expressed as follows: $Z=\frac{R O A+E / A}{\sigma(R O A)}$ where ROA is banks' Return on Assets, E/A is the ratio of equity to total assets, and $\sigma(R O A)$ is the standard deviation of Return on Assets.
} 
Table 2a Descriptive statistics for profitability measures of Chinese banking industry

\begin{tabular}{|l|l|l|l|l|l|}
\hline & Observations & Mean & Standard deviation & Minimum & Maximum \\
\hline ROA & 808 & 0.0088 & 0.0066 & -0.04 & 0.106 \\
\hline
\end{tabular}

Table $2 \mathrm{~b}$ Descriptive statistics for profitability measures of state-owned commercial banks

\begin{tabular}{|l|l|l|l|l|l|}
\hline & Observations & Mean & Standard deviation & Minimum & Maximum \\
\hline ROA & 55 & 0.009 & 0.004 & 0.0002 & 0.014 \\
\hline
\end{tabular}

Table 2c Descriptive statistics for profitability measures of joint-stock commercial banks

\begin{tabular}{|l|l|l|l|l|l|}
\hline & Observations & Mean & Standard deviation & Minimum & Maximum \\
\hline ROA & 127 & 0.006 & 0.006 & -0.04 & 0.0133 \\
\hline
\end{tabular}

Table 2d Descriptive statistics for profitability measures of city commercial banks

\begin{tabular}{|l|l|l|l|l|l|}
\hline & Observations & Mean & Standard deviation & Minimum & Maximum \\
\hline ROA & 626 & 0.0093 & 0.007 & -0.005 & 0.106 \\
\hline
\end{tabular}

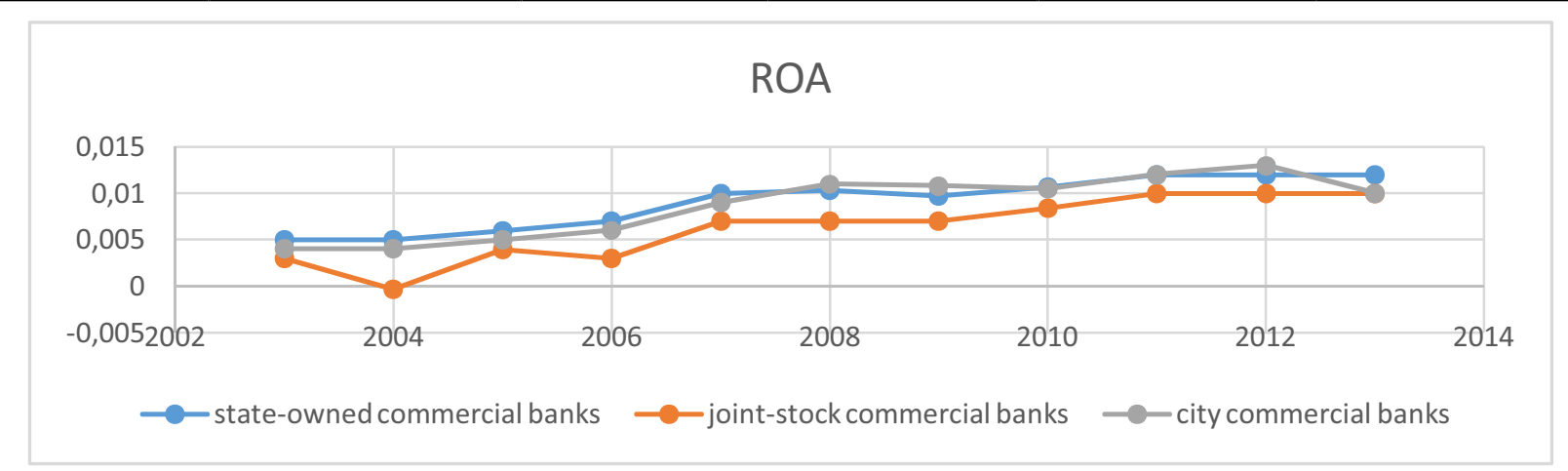

Fig. 1. The profitability of three different ownership types of Chinese commercial banks over the period 2003-2013

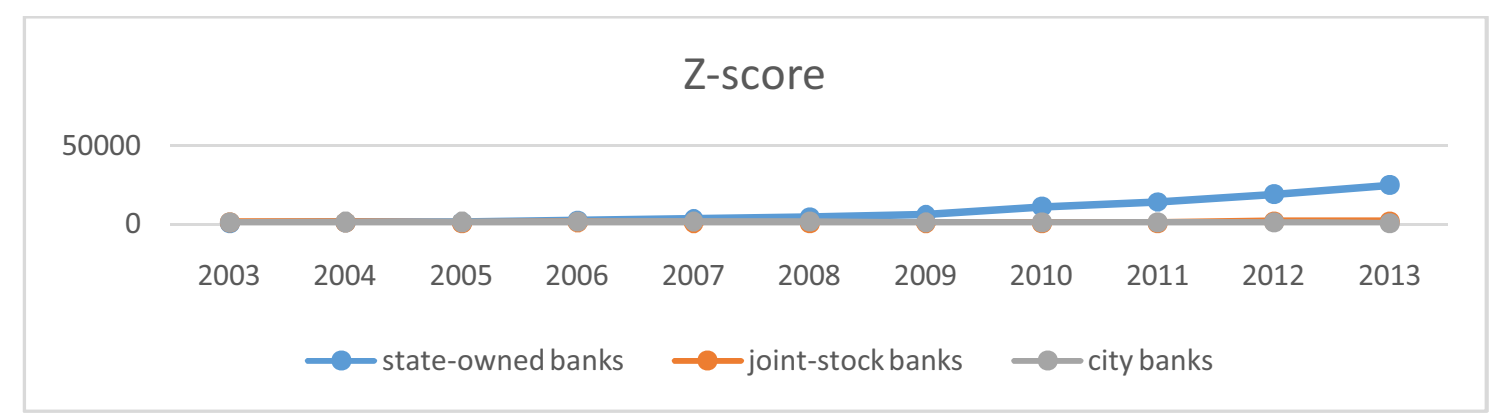

Fig. 2. insolvency risk (Z-score) of different ownership types of Chinese commercial banks: 2003-2013

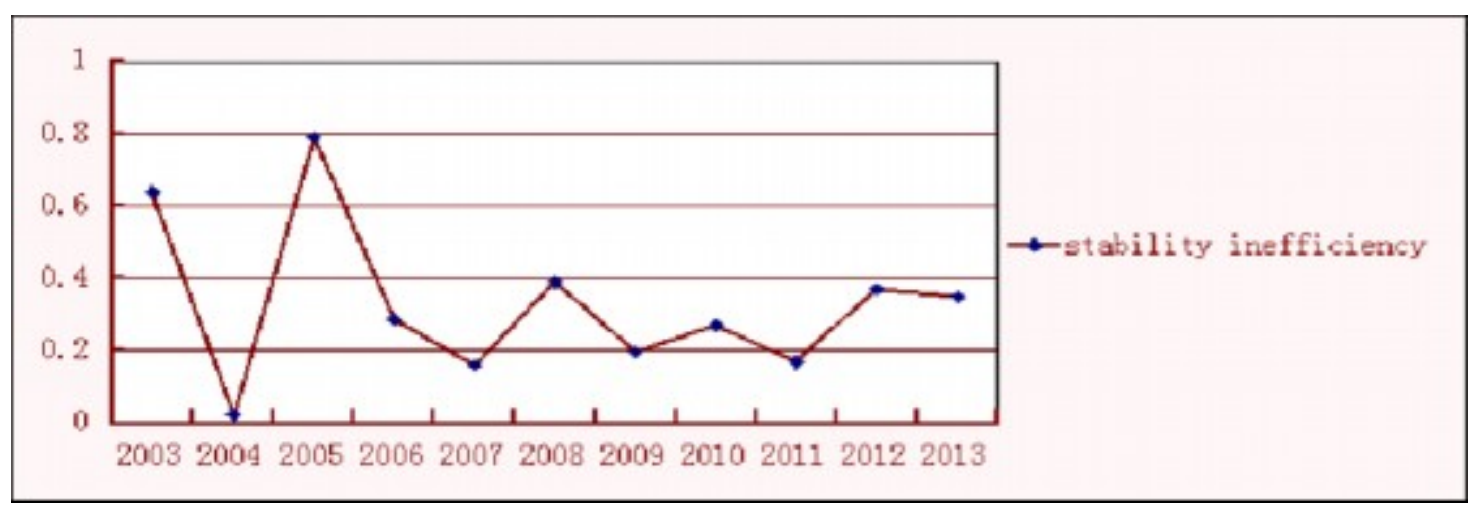

Fig. 3. Insolvency risk (stability inefficiency) in the Chinese banking industry: 2003-2013

Table 3. Unit root test for the variables

\begin{tabular}{|l|c|c|c|c|}
\hline ROA & T-stat & $1 \%$ critical value & $5 \%$ critical value & $10 \%$ critical value \\
\hline Z $(t)$ & -7.805 & -3.444 & -2.872 & -2.570 \\
\hline Mackinnon approximate $p$ value for $\mathrm{z}(\mathrm{t})=0.000$ & Coefficient & Standard deviation & $\mathrm{t}$ & $\mathrm{P}>\mathrm{t} \mid$ \\
\hline D. ROA & -0.53 & 0.07 & -7.81 & 0.000 \\
\hline L1 & \multicolumn{5}{|l|}{} \\
\hline
\end{tabular}


Investment Management and Financial Innovations, Volume 13, Issue 4, 2016

\begin{tabular}{|c|c|c|c|c|}
\hline LD & -0.36 & 0.07 & -5.21 & 0.000 \\
\hline L2d & -0.18 & 0.06 & -3.24 & 0.001 \\
\hline Constant & -0.007 & 0.001 & 9.69 & 0.000 \\
\hline $\log Z$ & T-stat & $1 \%$ critical value & $5 \%$ critical value & $10 \%$ critical value \\
\hline Stability inefficiency & T-stat & $1 \%$ critical value & $5 \%$ critical value & $10 \%$ critical value \\
\hline$Z(t)$ & -33.029 & -3.430 & -2.860 & -2.570 \\
\hline \multicolumn{5}{|c|}{ Mackinnon approximate $p$ value for $z(t)=0.000$} \\
\hline D. stability inefficiency & Coefficient & Standard deviation & $t$ & $P>|t|$ \\
\hline $\mathrm{L} 1$ & -1.19 & 0.04 & -33.03 & 0.000 \\
\hline LD & -0.02 & 0.03 & -0.59 & 0.557 \\
\hline L2D & -0.14 & 0.01 & -9.51 & 0.000 \\
\hline Constant & 0.33 & 0.01 & 28.34 & 0.000 \\
\hline$Z(t)$ & -5.086 & -3.430 & -2.860 & -2.570 \\
\hline \multicolumn{5}{|c|}{ Mackinnon approximate $p$ value for $z(t)=0.000$} \\
\hline D. $\log Z$ & Coefficient & Standard deviation & $\mathrm{t}$ & $P>|t|$ \\
\hline L1 & -0.2 & 0.04 & -5.09 & 0.000 \\
\hline LD & -0.2 & 0.05 & -4.16 & 0.000 \\
\hline L2d & -0.09 & 0.04 & -2.19 & 0.029 \\
\hline Constant & 1.51 & 0.29 & 5.22 & 0.000 \\
\hline
\end{tabular}

Table 4 Empirical results of the impact of insolvency risk on bank profitability

\begin{tabular}{|c|c|c|c|c|}
\hline ROA & Difference GMM & One-step system GMM & Two-step system GMM & Two-step system GMM robust \\
\hline $\mathrm{ROA}(-1)$ & $-0.38^{*}(-1.78)$ & $0.16(1.05)$ & $1.36^{* \star *}(4.68)$ & $-0.03(-0.17)$ \\
\hline $\mathrm{ROA}(-2)$ & $-0.17^{\star}(-1.76)$ & $0.18^{* * *}(3.13)$ & $-0.01(-0.15)$ & $0.19^{* * *}(3.40)$ \\
\hline Z-score(-1) & $0.001(1.10)$ & $-0.0001(-0.15)$ & $-0.001(-1.42)$ & $-0.0004(-0.92)$ \\
\hline Z-score $(-2)$ & $0.002^{* * \star}(3.03)$ & $0.001^{*}(1.79)$ & $0.001(1.13)$ & $0.0003(0.56)$ \\
\hline Prob $>F$ & 0.014 & 0.000 & 0.000 & 0.000 \\
\hline$A R(1)$ (p-value) & 0.054 & 0.000 & 0.129 & 0.006 \\
\hline AR(2) (p-value) & 0.276 & 0.354 & 0.325 & 0.17 \\
\hline Test $\beta_{1}+\beta_{2}=0$ (p-value) & 0.0075 & 0.000 & 0.55 & 0.178 \\
\hline $\begin{array}{l}\text { Sargan/Hansan test }(p- \\
\text { value) }\end{array}$ & 0.549 & 0.476 & 0.485 & 0.798 \\
\hline$\sum Z-$ score & $5.13^{* * *}$ & $13.08^{* * *}$ & 2.08 & 0.89 \\
\hline $\mathrm{ROA}(-1)$ & $-0.43^{* *}(-1.96)$ & $0.74^{\star * *}(5.38)$ & $-0.1(-1.61)$ & $-0.1(-0.56)$ \\
\hline $\mathrm{ROA}(-2)$ & $-0.17^{*}(-1.83)$ & $0.2^{* *}(2.59)$ & $0.12^{\star * *}(3.07)$ & $0.12^{* *}(2.05)$ \\
\hline $\mathrm{SI}(-1)$ & $-0.004^{\star *}(-2.18)$ & $0.001(0.65)$ & $-0.006^{* * *}(-6.07)$ & $-0.006^{* * *}(-3.78)$ \\
\hline $\mathrm{SI}(-2)$ & $-0.002(-1.32)$ & $0.004^{* *}(2.12)$ & $-0.003^{* * *}(-3.40)$ & $-0.003^{* *}(-2.15)$ \\
\hline Prob $>F$ & 0.134 & 0.000 & 0.000 & 0.000 \\
\hline AR(1) (p-value) & 0.111 & 0.000 & 0.141 & 0.179 \\
\hline AR(2) (p-value) & 0.315 & 0.517 & 0.118 & 0.273 \\
\hline Test $\beta_{1}+\beta_{2}=0$ (p-value $)$ & 0.06 & 0.102 & 0.000 & 0.0001 \\
\hline $\begin{array}{l}\text { Sargan/Hansan test }(p- \\
\text { value) }\end{array}$ & 0.412 & 0.396 & 1.000 & 1.000 \\
\hline$\sum S I$ & $2.44^{*}$ & 2.25 & $41.05^{\star \star \star}$ & $18.47^{\star \star *}$ \\
\hline
\end{tabular}

- Notes: the number outside the () represents coefficient, while the number in the () is t-stat; SI represents stability inefficiency. $. *, * *, * * *$ represents significance at $10 \%, 5 \%$ and $1 \%$ level, respectively.

Table 5 Empirical results of the impact of profitability on insolvency risk

\begin{tabular}{|l|c|c|c|c|}
\hline \multicolumn{1}{|c|}{ Z-score } & Difference GMM & One-step system GMM & Two-step system GMM & $\begin{array}{c}\text { Two-step system GMM } \\
\text { Robust }\end{array}$ \\
\hline Z-score(-1) & $-0.42^{* * *}(-11.17)$ & $1.01^{* * *}(16.91)$ & $1.06^{* * *}(49.01)$ & $1.06^{* * *}(7.49)$ \\
\hline Z-score(-2) & $-0.1^{* * *}(-3.72)$ & $-0.0003(-0.01)$ & $0.03^{* * *}(4.71)$ & $0.03(0.77)$ \\
\hline ROA (-1) & $2.56(1.07)$ & $-2.01(-0.49)$ & $-1.3(-0.85)$ & $-1.3(-0.52)$ \\
\hline ROA (-2) & $1.13(0.4)$ & $-0.73(-0.15)$ & $-4.51^{* * *}(-3.28)$ & $-4.51(-1.18)$ \\
\hline Prob>F & 0.000 & 0.000 & 0.000 & 0.000 \\
\hline AR(1) (p-value) & 0.000 & 0.000 & 0.151 & 0.158 \\
\hline AR(2) (p-value) & 0.846 & 0.613 & 0.221 & 0.283 \\
\hline
\end{tabular}




\begin{tabular}{|c|c|c|c|c|}
\hline Test $\beta_{1}+\beta_{2}=0$ (p-value $)$ & 0.34 & 0.6 & 0.01 & 0.18 \\
\hline Sargan/Hansan test (p-value) & 0.246 & 0.89 & 0.866 & 0.866 \\
\hline$\sum R O A$ & 0.61 & 0.17 & $10.74^{* \star *}$ & 1.79 \\
\hline $\mathrm{SI}(-1)$ & $-0.04(-0.24)$ & $-0.11(-0.54)$ & $-0.05^{\star * *}(-3.26)$ & $-0.45^{* * *}(-2.86)$ \\
\hline $\mathrm{SI}(-2)$ & $0.06(0.50)$ & $0.27^{* \star *}(4.97)$ & $0.06^{* \star \star}(2.63)$ & $0.06^{* \star *}(2.21)$ \\
\hline $\mathrm{ROA}(-1)$ & $0.74(0.56)$ & $10.23^{* \star *}(3.98)$ & $-0.13(-0.30)$ & $-0.13(-0.30)$ \\
\hline $\mathrm{ROA}(-2)$ & $-1.91(-1.28)$ & $8.63^{\star * \star}(2.86)$ & $-2.37^{* * *}(-5.12)$ & $-2.37^{* * *}(-5.02)$ \\
\hline Prob $>F$ & 0.042 & 0.000 & 0.000 & 0.000 \\
\hline$A R(1)$ (p-value) & 0.013 & 0.094 & 0.000 & 0.000 \\
\hline$A R(2)$ (p-value) & 0.880 & 0.644 & 0.650 & 0.667 \\
\hline Test $\beta_{1}+\beta_{2}=0$ ( $\mathrm{p}$ value $)$ & 0.31 & 0.0004 & 0.000 & 0.000 \\
\hline Sargan/Hansan test ( $p$ value) & 0.159 & 0.468 & 0.181 & 0.18 \\
\hline$\sum R O A$ & 1.04 & $7.97^{\star * \star}$ & $32.06^{* \star *}$ & $30.21^{\star \star \star}$ \\
\hline
\end{tabular}

Notes: the number outside the () represents coefficient, while the number in the () is t-stat, SI represents stability inefficiency. **, **, *** represents significance at $10 \%, 5 \%$ and $1 \%$ level, respectively.

Table 6 Robustness test: impact of insolvency risk on bank profitability

\begin{tabular}{|c|c|c|c|}
\hline ROA & Between effect & OLS & Fixed effect \\
\hline $\mathrm{ROA}(-1)$ & $0.998^{* * *}(22.27)$ & $0.18^{* \star *}(4.10)$ & $-0.13^{* * *}(-2.69)$ \\
\hline $\mathrm{ROA}(-2)$ & $-0.13^{* *}(-2.59)$ & $0.26^{\star * \star}(5.17)$ & $0.05(0.93)$ \\
\hline Z-score (-1) & $-0.0002(-0.27)$ & $-0.001(-1.48)$ & $0.002^{* \star *}(2.69)$ \\
\hline Z-score (-2) & $0.0001(0.24)$ & $0.0001(0.30)$ & $0.002^{* \star *}(3.72)$ \\
\hline$F$ test ( $p$ value) & 0.000 & 0.000 & 0.000 \\
\hline Test $\beta_{1}+\beta_{2}=0$ (p value) & 0.906 & 0.113 & 0.000 \\
\hline$\sum Z-$ score & 0.04 & 1.53 & $11.96^{* \star *}$ \\
\hline $\mathrm{ROA}(-1)$ & $1.001^{* * *}(24.53)$ & $0.16^{\star \star *}(3.80)$ & $-0.13^{\star * *}(-2.64)$ \\
\hline $\mathrm{ROA}(-2)$ & $-0.12^{* *}(-2.36)$ & $0.23^{\star \star *}(4.59)$ & $0.04(0.76)$ \\
\hline SI(-1) & $0.002(0.75)$ & $-0.004^{* *}(-2.02)$ & $-0.008^{* * *}(-4.04)$ \\
\hline SI(-2) & $0.002(1.15)$ & $-0.002(-1.31)$ & $-0.006^{* * *}(-3.55)$ \\
\hline $\mathrm{F}$ test ( $\mathrm{p}$ value) & 0.000 & 0.000 & 0.000 \\
\hline Test $\beta_{1}+\beta_{2}=0$ ( $\mathrm{p}$ value $)$ & 0.2356 & 0.0578 & 0.000 \\
\hline$\sum S I$ & 0.97 & 2.06 & $9.05^{* * *}$ \\
\hline
\end{tabular}

Notes: the number outside the () represents coefficient, while the number in the () is t-stat; SI represents stability inefficiency. ${ }^{*},{ }^{* *}$, $* * *$ represents significance at $10 \%, 5 \%$ and $1 \%$ level, respectively.

Table 7 Robustness test: the impact of profitability on insolvency risk

\begin{tabular}{|c|c|c|c|}
\hline Z-score & Between effect & OLS & Fixed effect \\
\hline Z-score(-1) & $1.02^{* * *}(16.03)$ & $0.61^{\star \star *}(13.38)$ & $0.13^{\star \star}(2.42)$ \\
\hline Z-score(-2) & $0.03(0.83)$ & $0.15^{\star \star \star}(3.99)$ & $-0.03(-0.74)$ \\
\hline $\mathrm{ROA}(-1)$ & $0.17(0.02)$ & $-2.76(-0.76)$ & $8.33^{* *}(2.31)$ \\
\hline $\mathrm{ROA}(-2)$ & $0.44(0.04)$ & $1.67(0.40)$ & $7.98^{* *}(1.98)$ \\
\hline $\mathrm{F}$ test ( $\mathrm{p}$ value) & 0.000 & 0.000 & 0.000 \\
\hline Test $\beta_{1}+\beta_{2}=0$ ( $\mathrm{p}$ value $)$ & 0.94 & 0.8058 & 0.001 \\
\hline$\sum R O A$ & 0.00 & 0.30 & $5.28^{* * *}$ \\
\hline SI(-1) & $-0.33^{* \star *}(-5.08)$ & $-0.43^{* \star *}(-11.50)$ & $-0.48^{* \star *}(-11.35)$ \\
\hline SI(-2) & $-0.01(-0.2)$ & $-0.1^{* \star *}(-3.08)$ & $-0.14^{\star \star \star}(-3.91)$ \\
\hline $\mathrm{ROA}(-1)$ & $-1.3(-1.12)$ & $-2.212^{\star \star}(-2.41)$ & $-3.08^{\star \star \star}(-2.85)$ \\
\hline $\mathrm{ROA}(-2)$ & $-1.34(-0.97)$ & $-4.18^{* \star *}(-4.27)$ & $-5.58^{* \star \star}(-4.71)$ \\
\hline$F$ test ( $p$ value) & 0.000 & 0.000 & 0.000 \\
\hline Test $\beta_{1}+\beta_{2}=0$ (p value) & 0.0093 & 0.000 & 0.000 \\
\hline$\sum R O A$ & $3.75^{* * *}$ & $16.85^{\star \star \star}$ & $16.65^{\star \star *}$ \\
\hline
\end{tabular}

Notes: the number outside the () represents coefficient, while the number in the () is t-stat; SI represents stability inefficiency. ${ }^{*},{ }^{* *}$, *** represents significance at $10 \%, 5 \%$ and $1 \%$ level, respectively. 